\title{
RAB7A: THE MASTER REGULATOR OF VESICULAR TRAFFICKING
}

\author{
Soumik BasuRay \\ Eugene McDermott Center for Human Growth and Development, Department of Molecular Genetics, \\ University of Texas Southwestern Medical Center, Dallas, TX, USA
}

The membrane flow of eukaryotic cells occurs through vesicles that bud from a donor compartment, move and fuse with an acceptor compartment. Rab (Ras-related in brain), which belong to the Ras superfamily of small GTPases, emerged as a central player of vesicle mobility in both secretory and endocytic pathway, Rab7a being a master regulator of late endocytic trafficking. Elucidation of how mutant or dysregulated Rab7 GTPase and accessory proteins contribute to organ specific and systemic disease remains an area of intensive study and an essential foundation for effective drug targeting. Mutation of Rab7 or associated regulatory proteins causes numerous human genetic diseases. Cancer and neurodegeneration represent examples of acquired human diseases resulting from the up- or down-regulation or aberrant function of Rab7. The broad range of physiologic processes affected by altered Rab7 activity is based on its pivotal roles in membrane trafficking and signaling. The Rab7-regulated processes of cargo sorting, cytoskeletal translocation of vesicles and appropriate docking and fusion with the target membranes control cell metabolism, growth and differentiation. In this review, role of Rab7 in endocytosis is evaluated to illustrate normal function and the consequences of dysregulation resulting in human disease. Selected examples are designed to illustrate how defects in Rab7 activity alter endocytic trafficking that underlie neurologic, lipid storage, and bone disorders as well as cancer. Biomed Rev 2014; 25: 67-81

Keywords: Rab7, small GTPases, vesicular trafficking, endocytosis, disease

\section{INTRODUCTION}

Mammalian Rab7 was first identified in a rat liver cell line as BRL-Ras (X12535;NM_023950) and subsequently named Rab7a upon recognition as a distinct member of Ras related GTPases now well known as the Rab family of GTPases (NP_004628.4;P51149;P09527). Rab7a is the most widely studied form and encoded on human chromosome 3q21.3 (mouse chromosome 6) as two splice variants differing in 3' untranslated region. The most intensively studied mammalian forms of Rab7a (mouse, canine, rat and human) are 99.5\% identical with only a single conservative change among 207 amino acids (D/E196). A more recently discovered homolog,

Received 12 December 2014, revised 21 December 2014, accepted 23 December 2014.

Correspondence to Dr Soumik BasuRay, Eugene McDermott Center for Human Growth and Development, Department of Molecular Genetics, University of Texas Southwestern Medical Center, 5323 Harry Hines Blvd. Dallas, TX 75390-9046, USA. Tel.: 214-648-5672, Fax: 214-648-7539, E-mail: soumik.basuray@gmail.com 
$\mathrm{Rab} 7 \mathrm{~b} / \mathrm{Rab} 7 \mathrm{~L} 1$, is encoded on human and mouse chromosome 1q32 and functions in late endosome to Golgi trafficking (1). Human Rab7b is only $47 \%$ identical and $82 \%$ homologus to Rab7a across its 199 amino acid length. Following the initial demonstration of Rab7a function in regulating membrane transport from early to late endosomes, Rab7a has established roles in autophagy, lipid metabolism, growth factor signaling, bone resorption and phagolysosome biogenesis (2).

\section{RAB7A: THE GOOD, THE BAD AND THE UGLY}

Rab7a belongs to the family of Ras superfamily of GTPases that plays a critical role in diverse cellular processes. The identification of the Ypt1p as a GTP binding protein in yeast led to the discovery of more than 70 Rab GTPases in the human genome (3-5). Rab7a was first cloned from a MDCK cell cDNA library (6) and later mapped in the mouse genome (7). Rab7a was conclusively shown to orchestrate membrane transport from early to late endosomes (8). This generated considerable interest to investigate the functionality of the protein and it is now known to play an important role in endocytic trafficking and other degradative pathways like phagocytocis and autophagy $(9,10)$. Rab7a regulates internalization and degradation of growth factor receptors $(11,12)$. This regulation is critical as overexpression of epidermal growth factor receptor (EGFR) is characterized in different types of cancer (13-15). Rab7a is pivotal in the trafficking of multivescicular bodies, melanosomes and exosomes $(16,17)$. It is also associated with lipid homeostasis that modulates membrane structure and organization, cell signaling, regulation of growth, cell cycle and differentiation (18). Osteoclasts involve Rab7a vesicular trafficking in bone resorption to maintain bone integrity (19). Rab7a is vital for axonal retrograde trafficking (20). At neuromuscular junction, $\mathrm{Rab} 7 \mathrm{a}$ regulates neurotrophin traffic (21). Inhibition of Rab7a activity cause endosomal accumulation of TrkA and pronounce enhancement of TrkA signaling in response to nerve growth factor (NGF) stimulation (21a). NGF has been implicated in a host of different cardiometabolic and neurological disorder (22). The endocytic role of Rab7a was further demonstrated in regulating trafficking of EGF-EGFR complex by controlling its lysosomal degradation (11, 12, 23-25). Similarly, ligand stimulated lysosomal degradation of platelet activating factor receptor (PAFR) depends on Rab7a in its delivery to the lysosomes (26). In concert with Rab5 and Rab11, Rab7a regulates intracellular trafficking patterns of angiotensin II type 1A receptor as exemplified by increased AT(1A)R degradation and AT(1A)R targeting to lysosomes in cell types with over-expressed Rab7a (27). In Chinese hamster ovary cells, agonist induced down regulation of the human kappa-opiod receptor (hkor) and inverse agonist upregulation of mutant rat $\mu$-opioid receptor is thought to be dependent on the endocytic pathway regulated by $\operatorname{Rab} 7 \mathrm{a}(28,29)$. Rab7a is indispensable in the delivery of autophagic cargo for degradation from autophagosomes to lysosomes $(9,30)$. It is thought to play a critical role in the final maturation of late autophagic vacuoles but not the initial maturation of early autophagosomes (31). Rab7a effects the degradation of autophagosomes by fusing the autophagosomes with the lysosomes and rapidly delivers of a complex of Beclin-1 binding UVRAG with class C Vps to lysosomes via late endosomes (32). Phagocytosis plays a vital role in development and immunity (33), and the maturation of phagosome to phagolysosome occurs by recruitment of Rab7a (34). Complete maturation is thought to be mediated by retrograde emission of tubular extensions generated by activation of Rab7a and its accessory proteins (35). Rab7a plays a role in melanosome biogenesis by sorting and associating with early and intermediate stage melanosomes (36). It is in the $\mathrm{T} 22 \mathrm{~N}$ dominant negative form in human amelanotic melanoma cells (SK-mel-24) impairs vesicular transport of tyrosinase and TRP-1 proteins from the trans-Golgi network to maturing melanosomes $(37,38)$. In MMAc melanoma cells, GTP bound (active) form of Rab7a promotes melanogenesis by regulating gp100 maturation (39). In a similar way, exosomal transport uses established endocytic pathway machinery to deliver cargo to extracellular environment of the cell. Exosomes help in the elimination of undegraded endosomal or lysosomal proteins and membranes (40). In dendritic cells, Rab7a is associated with exosome biogenesis and function that involve antigens transfer (41). Improper lipid homeostasis associated with disorders such as Niemann-Pick Type C (NPC) disease characterized by accumulation of lipids within late endosomes and lysosomes in tissues such as liver spleen and brain (42, 43). Overexpression of Rab7a in NPC disease fibroblasts dramatically improves intracellular trafficking of cholesterol and sphingolipids (44). Similarly accumulation of cholesterol in endosome membranes increases the amount of membrane associated Rab7a and inhibits Rab7a membrane extraction by guanine nucleotide dissociation inhibitor (45). Rab7a gene is also distinctly upregulated within hepatic and aortic tissues in a rabbit in response to cholesterol loading (46). In another scenario, Rab7a together with MTM1 are thought to serve as molecular switches controlling the sequential 
synthesis and degradation of endosomal $\mathrm{PI}_{3} \mathrm{P}(47,48)$. During cell differentiation, epithelial cells undergo epithelialmesenchymal transition (49). The change is marked by downregulation and inward sequestering of E-cadherin which is later trafficked via endocytic pathway to the lysosomes (49). Enhanced transport of the ubiquitinated E-cadherin to the lysosomes is accomplished by activated Rab7a catalyzed by Src kinase (50). Like E-cadherin transport, formation of ruffled border during bone resorption processes is usually accompanied by transport of acidic intracellular vesicles to the plasma membrane. This has been shown to involve regulatory role of Rab7a $(19,51)$. This is further confirmed by presence of Rab7a in rat osteoclasts which implies late endosomal nature of the plasma membrane domain in resorbing osteoclasts (52).

Rab7a is exploited to create a niche for the survival of many intracellular pathogens. Intracellular bacterial pathogens are thought to manipulate Rab function in the formation of vacuoles in their bid to colonize host cells during infection (53). Rab7 has a fundamental role in cellular vacuolation and vacuole growth $(54,55)$. In HeLa cells transfected with Rab7a mutants and then exposed to VacA cytotoxin, dominantnegative mutants of Rab7a prevent vacuolation confirming that membrane flow along the endocytic pathway is pertinent to vacuole growth $(55,56)$. In another study it is shown that interactions with the endocytic pathway controlled by Rab7a are key to Salmonella containing vacuole (SCV) biogenesis (57). Once entered into mammalian cells, Brucella abortus occupies Brucella containing vacuole (BCV) followed by acquisition of Rab7a and its effector Rab-interacting lysosomal protein to facilitate lysosomal delivery (58). Expression of dominant negative Rab7a or overexpression of RILP impairs the ability of bacteria to convert BCV into an ER-derived organelle thereby interfering with replication process (58). Like in higher organisms, the role of Rab7a in phagocytosis in lower organisms is quite prominent. In the enteric protozoan parasite Entamoeba histolytica, expression of either EhRab7aA or EhRab7aB-GTP mutant triggers a defect in phagocytosis accompanied with disturbed formation and disassembly of prephagosomal vacuoles (59).This implicates the two Rab7a isotypes in lysosome and phagosome biogenesis. In Dictyoselium discoideum, Rab7a homolog is thought to regulate fluid phase influx, efflux, retention of lysosomal hydrolases and phagocytosis (60-62). Phagosomes in cells overexpressing dominant negative Rab7a mature to form multiparticle spacious phagosomes which allude to Rab7a's role in regulating early and late steps of phagosomal maturation (61). In yeast, endocytosed pheromone alpha-factor accumulates in late endosomes in delta ypt7 cells, implicating Ypt7p (homolog of mammalian Rab7a protein) in endocytic pathway from late endosomes to the vacuole (63). Another report suggests the role of YPT7 GTPase in the uptake of the fluorescent styryl dye FM4-64 via the endocytic pathway to the vacuolar membrane (64). Transport fidelity is indispensable as evidenced by the increasing number of human diseases attributable to defects in endosomal trafficking and Rab7a specifically like Charcot-Marie-Tooth disease which is an autosomal dominant peripheral neuropathy (65-75). Rab7a sorts cargo on early endosomes by recruiting retromer complex (Vps26/29/35) that enables retrieval of cation independent mannose 6-phosphate receptor, TGN 38, Wntless among other cargo from early endosomes to the Golgi (76-78). Dysregulation of retromer is associated with other neurologic diseases like Alzheimer's disease $(79,80)$. In a macroscopic scale, its role in growth regulation is potentially important to the overall survival of the organism. The significant role it plays in pathogen entry, presents Rab7a as a potential therapeutic target.

In sum, Rab7 is indispensable in intracellular trafficking and signaling. However its role in diverse physiological processes is only beginning to be appreciated.

\section{REGULATION OF RAB7A ACTIVITY}

Typical of all Rab GTPases, Rab7a activity is modulated by membrane association and nucleotide binding (81) (Fig. 1). Membrane recruitment is dependent on the hypervariable, isoprenylated C-terminus (10, 82-84). Like all other Rabs, the presence of GDI on GDP bound Rab7a renders its delivery to the membrane a reversible process unless guanine nucleotide exchange factor (GEF) converts Rab7a into GTP bound form $(5,85)$. Unlike Rab5 with a known GEF as Rabex5, Rab7a GEF is still under investigation. The $\mathrm{hVps} 39$ protein whose yeast homolog Vps39 acts as a Ypt7GEF is premised to be a putative Rab7a GEF (86).Termination of nucleotide binding and Rab7a activation is achieved by GTPase activating protein (GAP). TBC1D15 was found to stimulate the intrinsic GTPase activity of Rab7a (87). Another regulatory mechanism with significant control on Rab7a activity is Rab5-Rab7a conversion. It confers directionality to membrane trafficking events leading to membrane maturation (85). It involves HOPS complex mediated recruitment of Rab7a on the Rab5 positive vesicles $(86,88)$.Vps 39 may also form a part of the complex (85). An increase in GFP-Rab7a density on endosomes of 


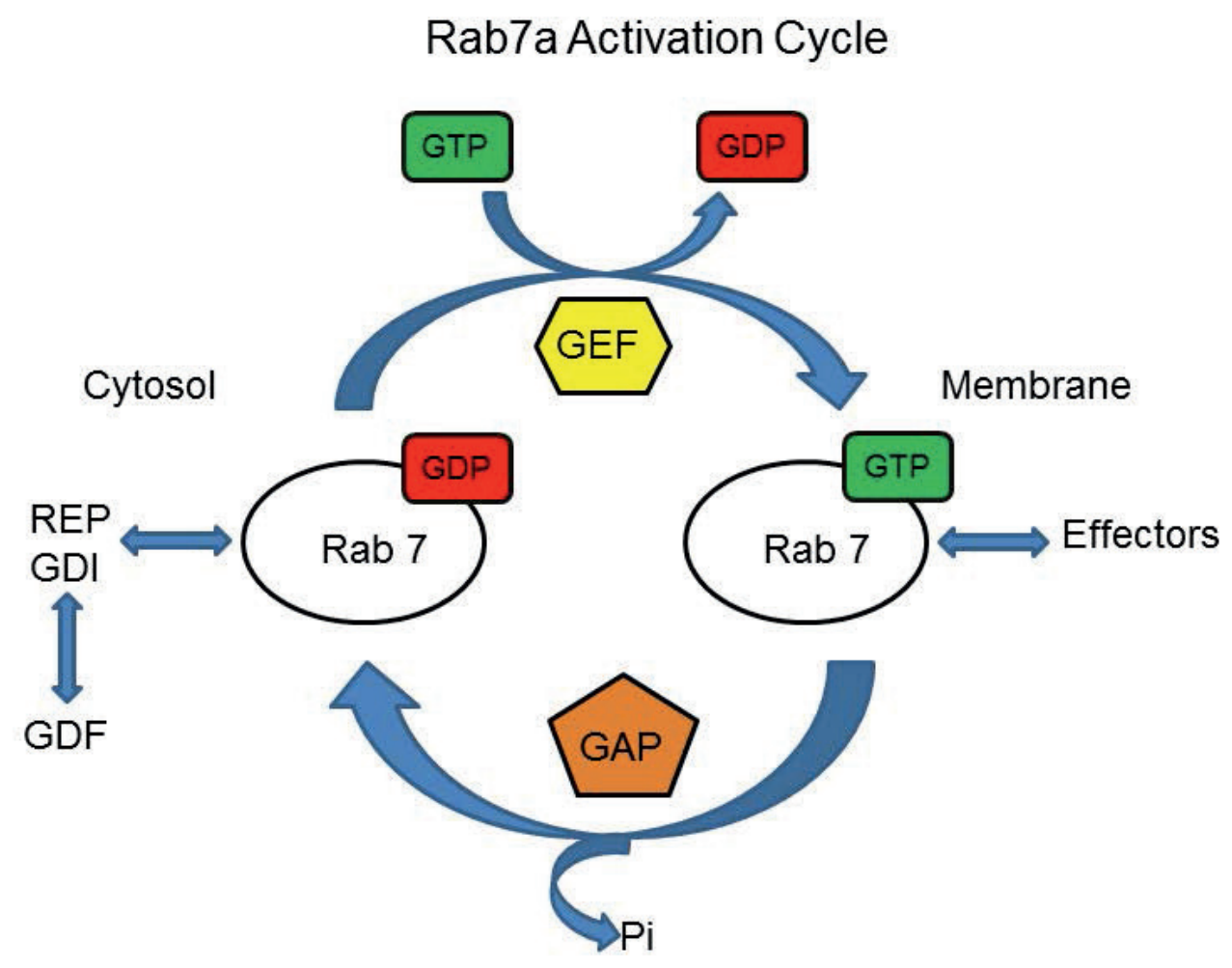

Figure1. Rab7a activation cycle. Newly synthesized Rab7a is prenylated by geranylgeranyl transferase (GGT) and delivered to endosomal membranes by rab escort protein (REP), thereafter Rab7a membrane cycling is facilitated by GDP dissociation inhibitor (GDI); pathways that are common to all Rab GTPases. A GDI displacement factor (GDF) has been implicated in membrane transfer by displacing the GDI. A guanine exchange factor (GEF) promotes activation and a GTPase activating protein (GAP) promotes hydrolysis and inactivation. Active, GTP-bound Rab7a act as a scaffold for sequentially binding multiple effectors (see Table1) to promote cargo selection, cytoskeletal translocation and membrane fusion.

A431 cells occurred with concomitant decay of GFP-Rab5 decay (89). Phosphorylation is a common activity regulation. Large scale proteomics analyses have identified Rab7a to be both serine and tyrosine phosphorylated. In mouse liver extracts, Rab7a was found phosphorylated on serine 72 within a highly conserved sequence near the GTP binding pocket (90). Rab7a was phosphorylated in response to EGF stimulation on tyrosine 183 in the $\mathrm{C}$ terminal region. Enhanced tyrosine 183 phosphorylation of Rab7a was also associated with mutant EGFR and HER2 expression in non-small cell lung carcinoma and mammalian epithelia respectively (91-93). Regulation of Rab7 activity has also been achieved by small molecule intervention of its nucleotide binding capacity. The small chemical molecule 2-(benzoylcarbamothioylamino)-5, 5dimethyl-4,7-dihydrothieno (2,3-c)pyran-3-carboxylic acid (PubChem CID 1067700) was shown to inhibit Rab7 activity in vitro $(94,95)$. This was the first report of inhibition of Rab7 activity and has potential therapeutic implications.

\section{RAB7A EFFECTORS CONTROL ENDOCYTIC TRAFFIC}

To date several effector proteins of Rab7a have been identified to interact specifically with the active GTP bound Rab7a (Table 1, Fig. 2). Rab7a effectors regulate events ranging from cargo selection to microtubule translocation to downstream membrane tethering and endosomal membrane fusion. Rab7a activation leads to dynamic assembly of large 


\section{Rab7 regulated trafficking pathways}

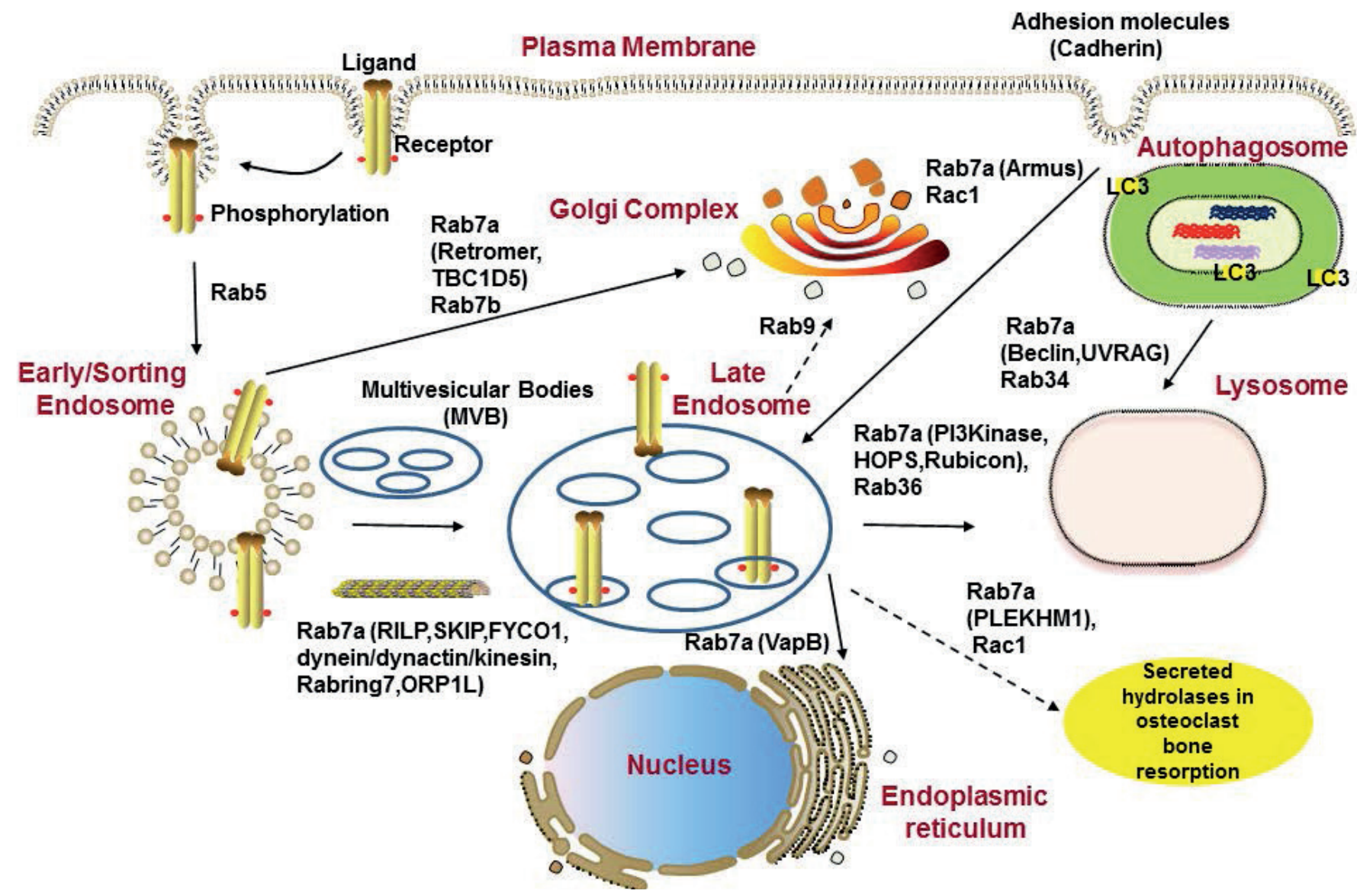

Figure2. Rab7 a regulated trafficking pathways. Rab7a regulated trafficking from early to late endosomes in a process requiring Rab5 to Rab7a conversion. Rab7a also cooperates with other Rab GTPases to facilitate late endosome-lysosome fusion and autophagolysosome formation (Table1). Key Rab7a effectors involved on individual pathways are noted in parentheses. Rab7a cooperates with Racl in epithelia promote internalization of cell adhesion molecules and in osteoclasts to promote localized hydrolase secretion for bone resorption.

protein complexes in a spatially and temporally regulated manner (96). Specific protein complexes serve discrete functions in the transport process yet handoffs and multiple layers of regulation are common. On multivescicular bodies and late endosomes Rab7a regulates cargo sorting and bidirectional transport by interacting with effectors that modulate kinesin and dynein activity. Lysosomal sorting and perinuclear transport are mediated by Rab7a interacting lysosomal protein (RILP) effector (97). RILP interacts with endosomal sorting complex components (ESCRT II, Vps22 and Vps36) and based on depletion studies, RILP is shown to participate in the sorting of ubiquitinated receptors into intraluminal vesicles (98). RILP facilitates the sorting and sequestration of cytosolic signaling machinery and targets them for lysosomal degradation. RILP is also targeted by bacterial pathogen to create a niche for its replication (99, 100). In a tripartite complex, Rab7a, RILP and ORP1L recruit a dynein/dynactin motor complex that in association 
Table1. Rab7 effectors and their roles in vesicular trafficking

\begin{tabular}{|c|c|c|}
\hline $\begin{array}{l}\text { Rab7a } \\
\text { isoform and } \\
\text { nucleotide } \\
\text { bound state }\end{array}$ & $\begin{array}{l}\text { Rab7a effector/ } \\
\text { binding partner }\end{array}$ & Regulator/effector function \\
\hline Rab7a & $\begin{array}{l}\text { ANKFY1(ankyrin repeat } \\
\text { andFYVEdomainprotein 1)/ } \\
\text { ANKHZN/Rabankyrin-5 }\end{array}$ & $\begin{array}{l}\text { Possible role in vesicular trafficking. Novel interactor of Rab7. Specific role yet to be } \\
\text { established }(70,113) .\end{array}$ \\
\hline Rab7a & ATP6 V0A1 & $\begin{array}{l}\text { Component of vacuolar ATPase that regulated organelle acidification required for } \\
\text { protein sorting, receptor mediated endocytosis, zymogen activation and synaptic } \\
\text { vesicle proton gradient. Novel Rab7 interactor }(70,114) \text {. }\end{array}$ \\
\hline Rab7a-GDP & $\begin{array}{l}\text { Ccz1 (vacuolar protein } \\
\text { trafficking and biogenesis } \\
\text { associated homolog) }\end{array}$ & $\begin{array}{l}\text { Recruited to endosomes by Mon } 1 \mathrm{a} / \text { Mon } 1 \mathrm{~b} \text { and acts as Rab7 GEF in yeast. Possible } \\
\text { human homolog C7orf28B also some similarity to HPS4 involved in biogenesis of } \\
\text { lysosome related organelles (115). }\end{array}$ \\
\hline Rab7a-GTP & $\begin{array}{l}\text { FYCO1(FYVE and coiled coil } \\
\text { domain containing 1) }\end{array}$ & $\begin{array}{l}\text { Promotes microtubule plus end transport of autophagosomes presumably by } \\
\text { functioning as a kinesin adaptor (116) }\end{array}$ \\
\hline Rab7a & $\begin{array}{l}\text { GNB2L1 ((guanine } \\
\text { nucleotide binding } \\
\text { protein,G protein),beta } \\
\text { polypeptide) }\end{array}$ & $\begin{array}{l}\text { Role in intracellular signaling and activation of protein kinase } C \text { and possible } \\
\text { interaction with Rab7 via WD40 domain. Novel interactor of Rab7. Specific role yet to be } \\
\text { determined (70). }\end{array}$ \\
\hline $\begin{array}{l}\text { Ypt7p/ } \\
\text { Rab7a-GTP }\end{array}$ & $\begin{array}{l}\text { HOPS complex (Vps11,-16,- } \\
18,-33,-39 \text { and }-41)\end{array}$ & $\begin{array}{l}\text { Involved in vacuolar tethering and fusion in yeast and conserved mammalian homologs } \\
\text { function in mammalian endolysosomal fusion. Interfaces with CORVET complex to } \\
\text { promote Rab5 to Rab7 conversion in yeast. Vps39 sub unit binds Mon1-Ccz1 complex } \\
\text { that serves as Rab7 GEF in C.elegans and yeast }(89,117,118) \text {. }\end{array}$ \\
\hline Rab7a & hVps39 & $\begin{array}{l}\text { In yeast Vps39p, cooperates with Mon1-Ccz1 complex to promote Ypt7p nucleotide } \\
\text { exchange. Function of mammalian protein remains to be determined }(118,119) \text {. }\end{array}$ \\
\hline Rab7a & IMMT (Mitofilin) & $\begin{array}{l}\text { Maintains mitochondrial morphology and suggested role in protein import. Novel } \\
\text { interactor of Rab7 (70). }\end{array}$ \\
\hline Rab7a & KIF3A (kinesin+adapter?) & $\begin{array}{l}\text { Kinesin2 heavy chain associates with late endosomes along with dynein, Rab7 and } \\
\text { dynactin. Possible mediator of Rab7-regulated anterograde transport coordinated by } \\
\text { Rab7 interacting adapter such as FYCO1 or other as yet unidentified protein (120). }\end{array}$ \\
\hline Rab7a-GDP & Mon1a-Mon 1b & $\begin{array}{l}\text { Mammalian homologs of C. elegans SAND1. Mon1a-Mon 1b causes Rab5 GEF } \\
\text { displacement and Mon 1b interacts with the HOPS complex. Mon1 is an effector of Rab5, } \\
\text { but only interacts with Rab7 when complexed with Ccz1 }(115,121-123) \text {. }\end{array}$ \\
\hline Rab7a-GTP & $\begin{array}{l}\text { ORP1L ((oxysterol-binding } \\
\text { protein,OSBP)-related } \\
\text { protein 1) }\end{array}$ & $\begin{array}{l}\text { Required for cholesterol sensing and regulation of dynein/dynactin motor with Rab7 } \\
\text { and RILP, regulates late endosome/lysosome morphogenesis and transport (101). }\end{array}$ \\
\hline Rab7a-GTP & $\begin{array}{l}\text { Phosphoinositide 3-kinase } \\
\text { complex (hVps34/hVps15) }\end{array}$ & $\begin{array}{l}\text { Typelll-PI3-kinase that generates phosphoinositide 3-phosphate to control endosomal } \\
\text { trafficking and signaling. Forms complex with myotubularins for negative regulation } \\
\text { (124). }\end{array}$ \\
\hline Rab7a-GTP & $\begin{array}{l}\text { Plekhm1 (Pleckstrin } \\
\text { homology domain } \\
\text { containing family } \mathrm{M} \text { (with } \\
\text { RUN domain member) }\end{array}$ & $\begin{array}{l}\text { Regulates lysosomal secretion in osteoclasts for bone resorption by interacting with } \\
\text { LIS1 to control microtubule transport and Rab7 and PI3Kinase to recruit effectors for } \\
\text { fusion (125). }\end{array}$ \\
\hline Rab7a & Prohibitin & $\begin{array}{l}\text { Negative regulator of cell proliferation and a possible tumor suppressor. Novel } \\
\text { interactor of Rab7, specific role yet to be established (70). }\end{array}$ \\
\hline Rab7a-GTP & Rabring7 & $\begin{array}{l}\text { Rab7-interacting ring finger protein, functions as E3 ligase that ubiquitylates itself and } \\
\text { controls EGFR degradation (126). }\end{array}$ \\
\hline
\end{tabular}


Table 1 continued.

\begin{tabular}{|c|c|c|}
\hline $\begin{array}{l}\text { Rab7a } \\
\text { isoform and } \\
\text { nucleotide } \\
\text { bound state }\end{array}$ & $\begin{array}{l}\text { Rab7a effector/ } \\
\text { binding partner }\end{array}$ & Regulator/effector function \\
\hline Rab7a-GDP & REP1 (Rab Escort protein1) & $\begin{array}{l}\text { Presents Rab7 to Rab geranylgeranyl transferase for addition of prenyl group that acts } \\
\text { as a membrane anchor (96). }\end{array}$ \\
\hline Rab7a-GTP & $\begin{array}{l}\text { Retromer } \\
\text { (Vps26,Vps29,Vps35) }\end{array}$ & $\begin{array}{l}\text { Regulates retrograde transport from late endosome to trans-Golgi network (TGN) } \\
\text { through direct interaction with Vps26 (127). }\end{array}$ \\
\hline Rab7a-GTP & $\begin{array}{l}\text { RILP (Rab7 Interacting } \\
\text { Lysosomal Protein) }\end{array}$ & $\begin{array}{l}\text { Involved in late endosomal/lysosomal maturation. Recruits dynein/dynactin motor } \\
\text { protein complex (128). }\end{array}$ \\
\hline Rab7a-GTP & Rubicon & $\begin{array}{l}\text { Regulates endosomal maturation through differential interaction with UVRAG and } \\
\text { Rab7. Rubicon binding inhibits UVRAG by binding to active Rab7 frees UVRAG to } \\
\text { activate the hVps34/hVps15 complex and HOPS thereby simultaneously increasing the } \\
\text { active pool of Rab7 and PI3P signaling (129). }\end{array}$ \\
\hline Rab7a-GTP & $\begin{array}{l}\text { SKIP (SifA and kinesin } \\
\text { interacting protein) }\end{array}$ & $\begin{array}{l}\text { Homolog of PLEKHM1 that binds Rab7, Rab9 and kinesin-1 and may regulate } \\
\text { anterograde motility of late endosomes. Target of Salmonella SifA protein }(130,131) \text {. }\end{array}$ \\
\hline Rab7a & Spg21 & $\begin{array}{l}\text { Loss of function causes autosomal recessive hereditary spastic paraplegia. Involved in } \\
\text { vesicular transport. Novel interactor of Rab7. Specific role yet to be established (70). }\end{array}$ \\
\hline Rab7a & STOML2 (Stomatin-like 2) & $\begin{array}{l}\text { Negatively modulates mitochondrial sodium/calcium exchange. Novel interactor of } \\
\text { Rab7. Specific role yet to be established (70). }\end{array}$ \\
\hline Rab7a-GTP & $\begin{array}{l}\text { TBC1D2 ((tre-2/ } \\
\text { USP6,BUB2,cdc16) domain } \\
\text { family,member5)/Armus } \\
\text { and Rac1 }\end{array}$ & $\begin{array}{l}\text { Regulates cytoskeletal organization, ruffled border formation in osteoclasts and } \\
\text { E-cadherin/adherens junction degradation in conjunction with Rac1, inactivates Rab7 } \\
\text { through C-terminal GAP activity }(132,133) \text {. }\end{array}$ \\
\hline Rab7a-GTP & $\begin{array}{l}\text { TBC1D5 ((tre-2/ } \\
\text { USP6,BUB2,cdc16) domain } \\
\text { family,member 5) }\end{array}$ & $\begin{array}{l}\text { Negatively regulates retromer recruitment and causes Rab7 to dissociate from } \\
\text { membrane and may have Rab7GAP activity (77). }\end{array}$ \\
\hline Rab7a-GTP & $\begin{array}{l}\text { TBC1D15 ((tre-2/ } \\
\text { USP6,BUB2,cdc16)domain } \\
\text { family,member } 15\end{array}$ & $\begin{array}{l}\text { Functions as Rab7 GAP and reduces interaction with RILP, fragments lysosomes and } \\
\text { confers resistance to growth factor withdrawalinduced cell death }(87,119) \text {. }\end{array}$ \\
\hline Rab7a-GTP & $\begin{array}{l}\text { TrkA (neurotrophic tyrosine } \\
\text { kinase receptor) }\end{array}$ & $\begin{array}{l}\text { Interacts with Rab7 and regulates endocytic trafficking and nerve growth factor } \\
\text { signaling as well as well as influencing neurite outgrowth }(22,68) \text {. }\end{array}$ \\
\hline Rab7a-GTP & $\begin{array}{l}\text { UVRAG (UV radiation } \\
\text { resistance associated } \\
\text { gene)/Beclin } 1\end{array}$ & $\begin{array}{l}\text { UVRAG/C-Vps complex positively regulates Rab7 activity via PI3kinase complex during } \\
\text { autophagic and endocytic maturation (32). }\end{array}$ \\
\hline Rab7a-GTP & $\begin{array}{l}\text { VapB ((Vesicle associated } \\
\text { membrane protein)- } \\
\text { associated protein B) }\end{array}$ & $\begin{array}{l}\text { Involved in mediating endosome-ER interaction in response to ORP1L conformation } \\
\text { sensing low cholesterol levels (102). }\end{array}$ \\
\hline Rab7a & $\begin{array}{l}\text { Vps13c (vacuolar protein } \\
\text { sorting 13c) }\end{array}$ & $\begin{array}{l}\text { Vacuolar protein sorting and novel interactor of Rab7. Specific role yet to be established } \\
\text { (70). }\end{array}$ \\
\hline $\begin{array}{l}\text { Rab7a- } \\
\text { GDP,GTP }\end{array}$ & $\begin{array}{l}\text { XAPC7/PSMA7 (proteasome } \\
\text { subunit, alpha type7) }\end{array}$ & $\begin{array}{l}\text { Negative regulator of late endocytic transport. Overexpression inhibits EGFR } \\
\text { degradation (110). }\end{array}$ \\
\hline Rab7b & SP-A (Surfactant protein A) & $\begin{array}{l}\text { Transiently enhances the expression of Rab7 and Rab7b and makes them functionally } \\
\text { active to increase the endolysosomal trafficking in alveolar macrophages (134). }\end{array}$ \\
\hline
\end{tabular}


with betaIII spectrin transports endosomes to the perinuclear region on microtubules (101-103). Endosomal lipids like cholesterol and phosphoinositides are critical regulators of cargo sorting and transport on the late endosomal pathway that are integrated with transport through the Rab7a effector ORP1L. When cholesterol levels are low, ORP1L promotes association of late endosomes with endoplasmic reticulum by dissociating minus end motor proteins. The ER protein VAPB contributes to motor dissociation and the peripheral movement of late endosomes. Being more peripherally localized, late endosomes are poised to receive cholesterol from early endosomes or ER. When cholesterol levels are high the conformation of ORP1L is altered and perinuclear transport is favored. In NPC disease where endosomal cholesterol levels are high the bidirectional motility of endosomes are perturbed that contribute to disease pathology and can be reversed by overexpressing Rab7a and Rab9 $(107,108)$. Membrane associated scaffolding protein huntingtin (Htt) helps in dynein/ dynactin mediated perinuclear positioning. The mutant form of this protein causes Huntington's disease $(2,104)$. Huntingtin and Htt-associated protein of 40kD (HAP40) are known Rab5 effectors that orchestrates transport between tubulin- and actin-based networks, though the link with Rab7a remains unclarified. Anterograde movement of endosomes to the cell periphery along the microtubular network is incompletely characterized. Plus end motility of the autophagosomes is coordinated by FYVE and coiled coil domain protein 1 FYCO1 and an unknown kinesin (96). Late endosomal movement depends on kinesin2-KIF3A heavy chain while the Rab7a link and effector remain unknown (105). Rab9 and Rab7a have been shown to interact with distinct domains on SifA and kinesin interacting protein (SKIP), implicating kinesin-1 in anterograde motility and late endosomal sorting (106). Similar to Rab5 on early endosomes, GTP bound Rab7a is required for classIII phosphatidyl inositol 3-kinase (consisting of $\mathrm{hVps} 34$ catalytic, the hVps15/p150 Rab7a adaptor and Rubicon regulatory subunits) activation on late endosomes $(2,109)$. The synthesis of $\mathrm{PI}_{3} \mathrm{P}$ on endosomes recruit FYVE domain containing protein that promote membrane remodeling (including intraluminal vesicle formation) and eventually terminate the signal. Together these downstream effectors control endolysosome morphology, membrane trafficking, acidification among other functions. Rab7a together with the early endosomal myotubularin lipid phosphatases (MTM1) and late endosomal myotubularin related protein 2 (MTMR2) acts as a molecular switch regulating the sequential synthesis and degradation of endosomal $\mathrm{PI}_{3} \mathrm{P}$ (47). The phosphatases bind directly to the phosphatidyl inositol 3-kinase complex leading to inactivation of the myotubularins. The interaction of lipid kinase to myotubularin precludes the interaction of Rab7a with lipid kinase illustrating the importance of protein hand-offs in phosphoinositide 3-phosphate homeostasis on late endosomes. Together the examples cited provide evidence for a Rab7a function in endosomal lipid homeostasis in both metabolism and signaling, disruption of which leads to human disease. Rab7a interacting proteins like Rabring7 (Rab7a interacting ring finger protein) and XAPC7 have been reported to facilitate cargo degradation. Rabring7 functions as an E3 ligase in conjunction with the Ubc4 and Ubc5 as E2 proteins $(96,108)$. Overexpression of Rabring7 leads to degradation of EGFR and lysosome biogenesis. The proteasome subunit XAPC7 or PSMA7 in mammals interacts specifically with Rab7a and is recruited to late multivescicular endosomes (110). Overexpression of XAPC7 impairs late endocytic transport of EGFR and hence is a negative regulator of trafficking (111). Together Rabring7 and XAPC7 may coordinate the degradation of ubiquitinated growth factor receptors via a link to the proteasomal degradation machinery. There are many more putative effectors of Rab7a whose functions remain to be established. Therefore further complexity in Rab7a mediated sorting, cytoskeletal transport and membrane fusion will emerge. An important area that calls for attention is the interaction of Rab7a with the tethering factors and SNARE proteins in the endosomal fusion events that have been primarily characterized for yeast homolog Ypt7p (112).

\section{CONCLUSION}

Ever since Rab7a was discovered its role in endosomal trafficking have remained under investigation. The indefatigable interest is attributed to its diverse role in human disease. The list of Rab7a effectors continue to grow although their functions remain to be established. Elucidating regulation of Rab7 nucleotide exchange and hydrolysis and the mechanism of its recruitment to specific macromolecular complexes to regulate individual pathways remain important areas for further investigation.

\section{REFERENCES}

1. Progida C, Cogli L, Piro F, De Luca A, et al., Rab7b controls trafficking from endosomes to the TGN. $J$ Cell Sci 2010; 123 (Pt 9): 1480-1491. DOI10.1242/jcs.051474 
2. Agola JO, Jim PA, Ward HH, BasuRay S, Wandinger-Ness A. Rab GTPases as regulators of endocytosis, targets of disease and therapeutic opportunities. Clin Genet 2011; 80: 305-318. DOI10.1111/j.1399-0004.2011.01724.x

3. Stenmark H, Olkkonen VM. The Rab GTPase family. Genome Biol 2001; 2:reviews3007-1-3007-7.

4. Touchot N, Chardin P, Tavitian A. Four additional members of the ras gene superfamily isolated by an oligonucleotide strategy: molecular cloning of YPTrelated cDNAs from a rat brain library. Proc Natl Acad Sci USA 1987; 84: 8210-8214. DOI: 10.1038/35052055

5. Zerial M, McBride H. Rab proteins as membrane organizers. Nat Rev Mol Cell Biol 2001. 2: 107-117. DOI: $10.1038 / 35052055$

6. Chavrier P, Vingron M, Sander C, Simons, K, Zerial, M. Molecular cloning of YPT1/SEC4-related cDNAs from an epithelial cell line. Mol Cell Biol 1990; 10: 6578-6585.

7. Barbosa MD, Johnson S A, Achey K,Gutierrez M J, Wakeland E K, Zerial M, et al. The Rab protein family: genetic mapping of six Rab genes in the mouse. Genomics 1995; 30: 439-444. DOI: 10.1006/geno.1995.1262

8. Feng Y, Press B, Wandinger-Ness A. Rab 7: an important regulator of late endocytic membrane traffic. J Cell Biol 1995; 131 (6 Pt 1): 1435-1452.

9. Gutierrez MG, Munafo D B, Beron W, Colombo M I. Rab7 is required for the normal progression of the autophagic pathway in mammalian cells. J Cell Sci 2004. 117 (Pt 13): 2687-2697. DOI: 10.1242/jcs.01114

10. Schwartz SL, Cao C, Pylypenko O, Rak A, WandingerNess A. Rab GTPases at a glance. J Cell Sci 2007; 120 (Pt 22): 3905-3910. DOI: 10.1242/jcs.015909

11. Edinger A L, Cinalli R M, Thompson C B. Rab7 prevents growth factor-independent survival by inhibiting cellautonomous nutrient transporter expression. Dev Cell 2003; 5:571-582.

12. Snider M D. A role for rab7 GTPase in growth factorregulated cell nutrition and apoptosis. Mol Cell 2003; 12: 796-797.

13. Alonso-Curbelo D, Riveiro-FalkenbachE, PerezGuijarro E, Cifdaloz M, Karras P, Osterloh L, Megias $\mathrm{D}$, et al., RAB7 controls melanoma progression by exploiting a lineage-specific wiring of the endolysosomal pathway. Cancer Cell 2014; 26: 61-76. DOI: 10.1016/j. ccr.2014.04.030

14. Steffan J J, Dykes S S, Coleman D T, Adams L K, Rogers D, Carroll J L, et al., Supporting a role for the GTPase
Rab7 in prostate cancer progression. PLoS One 2014; 9: e87882. DOI: 10.1371/journal.pone.0087882

15. Ye Y, Gao J X,Tian H, Yearsley K, Lange A R, et al., Early to intermediate steps of tumor embolic formation involve specific proteolytic processing of E-cadherin regulated by Rab7. Mol Cancer Res 2012; 10:713-726. DOI: 10.1158/1541-7786.MCR-12-0009

16. de Gassart A, Geminard C, Hoekstra D, Vidal M. Exosome secretion: the art of reutilizing nonrecycled proteins? Traffic 2004; 5: 896-903. DOI: 10.1111/j.16000854.2004.00223.x

17. Bertram E M, Hawley R G, Watts T H. Overexpression of rab7 enhances the kinetics of antigen processing and presentation with MHC class II molecules in B cells. Int Immunol 2002; 14:309-318.

18. Kolesnick R N, Goni FM,AlonsoA.Compartmentalization of ceramide signaling: physical foundations and biological effects. J Cell Physiol 2000. 184: 285-300. DOI: 10.1002/1097-4652(200009)

19. Mulari M, Vaaraniemi J, Vaananen H K. Intracellular membrane trafficking in bone resorbing osteoclasts. Microsc Res Tech 2003; 61: 496-503. DOI: 10.1002/ jemt.10371

20. Ng E L,Tang B L, Rab GTPases and their roles in brain neurons and glia. Brain Res Rev, 2008; 58: 236-246. DOI: 10.1016/j.brainresrev.2008.04.006

21. Deinhardt K, Salinas S, Verastegui C, Watson R, Worth D, Hanrahan S, et al., Rab5 and Rab7 control endocytic sorting along the axonal retrograde transport pathway. Neuron 2006; 52: 293-305. DOI: 10.1016/j. neuron.2006.08.018

21a. Saxena S, Bucci C, Weis J, Kruttgen A. The small GTPase Rab7 controls the endosomal trafficking and neuritogenic signaling of the nerve growth factor receptor TrkA. J Neurosci 2005; 25:10930-10940. DOI: 10.1523/JNEUROSCI.2029-05.2005

22. Yanev S, Luigi A, Fiore M, Chaldakov GN. Neurotrophic and metabotrophic potential of nerve growth factor and brain-derived neurotrophic factor: Linking cardiometabolic and neuropsychiatric diseases. World $J$ Pharmacol 2013;2:982-992 DOI: 10.5497/wjp.v2.i4.92

23. Sokolova I P, Arnautov A M, Nikol'skii N N, Kornilova E S. Studies of small GTPase Rab7 association with endosomes of cells expressing normal and mutant forms of epidermal growth factor receptors. Tsitologiia 1998. 40: $862-868$. 
24. Ceresa B P, Bahr S J. Rab7 activity affects epidermal growth factor:epidermal growth factor receptor degradation by regulating endocytic trafficking from the late endosome. J Biol Chem, 2006. 281:1099-1106. DOI: $10.1074 /$ jbc.M504175200

25. Taub N, Teis D,Ebner H L, Hess M W, Huber L A. Late endosomal traffic of the epidermal growth factor receptor ensures spatial and temporal fidelity of mitogen-activated protein kinase signaling. Mol Biol Cell, 2007; 18: 46984710. DOI: $10.1091 / \mathrm{mbc} . \mathrm{E07-02-0098}$

26. Dupre DJ, Chen Z, Le Gouill C, Theriault C, Parent JL, Rola-Pleszczynski M, et al., Trafficking, ubiquitination, and down-regulation of the human platelet activating factor receptor. J Biol Chem 2003; 278: 48228-48235. DOI: 10.1074/jbc.M304082200

27. Dale L B, Seachrist J L, Babwah A V, Ferguson S S. Regulation of angiotensin II type $1 \mathrm{~A}$ receptor intracellular retention, degradation, and recycling by Rab5, Rab7, and Rab11 GTPases. J Biol Chem 2004; 279: 13110-8. DOI: $10.1074 / j b c . M 313333200$

28. Li J, Chen C, Huang P, Liu-Chen L Y. Inverse agonist up-regulates the constitutively active D3.49(164)Q mutant of the rat mu-opioid receptor by stabilizing the structure and blocking constitutive internalization and down-regulation. Mol Pharmacol 2001; 60: 1064-1075.

29. Li J G, Benovic J L, Liu-Chen L Y. Mechanisms of agonist-induced down-regulation of the human kappaopioid receptor: internalization is required for downregulation. Mol Pharmacol 2000; 58: 795-801.

30. Eskelinen E L. Maturation of autophagic vacuoles in mammalian cells. Autophagy 2005; 1: 1-10.

31. Jager S, Bucci C, Tanida I, Ueno T, Kominami E, Saftig $\mathrm{P}$, et al. Role for Rab7 in maturation of late autophagic vacuoles. J Cell Sci, 2004. 117(Pt 20): 4837-48. DOI: $10.1242 /$ jcs. 01370

32. Liang C, Lee J S, Inn K S, Gack M U, Li Q, Roberts E A, et al., Beclin1-binding UVRAG targets the class $\mathrm{C}$ Vps complex to coordinate autophagosome maturation and endocytic trafficking. Nat Cell Biol, 2008. 10: 77687.DOI: $10.1038 / \mathrm{ncb} 1740$

33. Scott P. Development and regulation of cell-mediated immunity in experimental leishmaniasis. Immunol Res 2003; 27: 489-498.DOI: 10.1385/IR:27:2-3:489

34. Saito F, Kuwata H, Oiki E, Koike M, Uchiyama Y, Honda $\mathrm{K}$, et al., Inefficient phagosome maturation in infant macrophages. Biochem Biophys Res Commun 2008. 375:
113-118. DOI: 10.1016/j.bbrc.2008.07.141

35. Harrison R E, Bucci C, Vieira O V, Schroer T A, Grinstein S. Phagosomes fuse with late endosomes and/ or lysosomes by extension of membrane protrusions along microtubules: role of Rab7 and RILP. Mol Cell Biol 2003. 23: 6494-6506.

36. Jordens I, Westbroek W, Marsman M, Rocha N, Mommaas M, Huizing M. et al., Rab7 and Rab27a control two motor protein activities involved in melanosomal transport. Pigment Cell Res 2006; 19: 412-423. DOI: 10.1111/j.1600-0749.2006.00329.x

37. Gomez P F, Luo D, Hirosaki K, Shinoda K, Yamashita T, Suzuki J, et al. Identification of rab7 as a melanosomeassociated protein involved in the intracellular transport of tyrosinase-related protein 1. J Invest Dermatol 2001; 117: 81-90. DOI: 10.1046/j.0022-202x.2001.01402.x

38. Hirosaki K, Yamashita T, Wada I, Jin H Y, Jimbow K. Tyrosinase and tyrosinase-related protein 1 require Rab7 for their intracellular transport. J Invest Dermatol 2002; 119: 475-480. DOI: 10.1046/j.1523-1747.2002.01832.x

39. Kawakami A, Sakane F, Imai S, Yasuda S, Kai M, Kanoh $\mathrm{H}$, et al., Rab7 regulates maturation of melanosomal matrix protein gp100/Pmel17/Silv. J Invest Dermatol, 2008; 128: 143-150. DOI: 10.1038/sj.jid.5700964

40. Thery C, Zitvogel L, S. Amigorena. Exosomes: composition, biogenesis and function. Nat Rev Immunol 2002; 2: 569-579. DOI: $10.1038 /$ nri855

41. Thery C, Boussac M, Veron P, Ricciardi-Castagnoli P, Raposo G, Garin J, et al., Proteomic analysis of dendritic cell-derived exosomes: a secreted subcellular compartment distinct from apoptotic vesicles. J Immunol 2001; 166: 7309-7318.

42. Liscum L. Niemann-Pick type $\mathrm{C}$ mutations cause lipid traffic jam. Traffic 2000; 1: 218-225.

43. Ory D S. Niemann-Pick type C: a disorder of cellular cholesterol trafficking. Biochim Biophys Acta 2000; 1529: 331-339.

44. Choudhury A, Sharma D K, Marks D L, Pagano R E. Elevated endosomal cholesterol levels in Niemann-Pick cells inhibit rab4 and perturb membrane recycling. $\mathrm{Mol}$ Biol Cell 2004; 15: 4500-4511. DOI: 10.1091/mbc.E0405-0432

45. Lebrand C, Corti M, Goodson H, Cosson P, Cavalli V, et al., Late endosome motility depends on lipids via the small GTPase Rab7. EMBO J 2002; 21: 1289-300. DOI: 10.1093/emboj/21.6.1289 
46. Kim J Y, Jang M K, Lee S S, Choi M S, Bok S H, et al., Rab7 gene is up-regulated by cholesterol-rich diet in the liver and artery. Biochem Biophys Res Commun 2002. 293: 375-82. DOI: 10.1016/S0006-291X(02)00173-0

47. Cao C, Backer J M, Laporte J, Bedrick E J, WandingerNess A. et al., Sequential actions of myotubularin lipid phosphatases regulate endosomal PI(3)P and growth factor receptor trafficking. Mol Biol Cell 2008; 19: 33343346. DOI: 10.1091/mbc.E08-04-0367

48. Cao C, Laporte J, Backer J M, Wandinger-Ness A, Stein M P, et al., Myotubularin lipid phosphatase binds the hVPS15/hVPS34 lipid kinase complex on endosomes. Traffic 2007; 8: 1052-1067. DOI: 10.1111/j.16000854.2007.00586.x

49. Emery G, Knoblich J A. Endosome dynamics during development. Curr Opin Cell Biol 2006; 18: 407-415. DOI: 10.1016/j.ceb.2006.06.009

50. Palacios F, Tushir J S, Fujita Y, D'Souza-Schorey C. Lysosomal targeting of E-cadherin: a unique mechanism for the downregulation of cell-cell adhesion during epithelial to mesenchymal transitions. Mol Cell Biol 2005; 25: 389-402. DOI: 10.1128/MCB.25.1.389402.2005

51. Palokangas H, Mulari M, Vaananen H.K. Endocytic pathway from the basal plasma membrane to the ruffled border membrane in bone-resorbing osteoclasts. J Cell Sci 1997; 110 (Pt 15): 1767-1780.

52. Zhao S, Zhang Y K, Harris S, Ahuja S S, Bonewald L F. MLO-Y4 osteocyte-like cells support osteoclast formation and activation. J Bone Miner Res 2002. 17: 2068-2079. DOI: 10.1359/jbmr.2002.17.11.2068

53. Brumell J H and Scidmore M A. Manipulation of rab GTPase function by intracellular bacterial pathogens. Microbiol Mol Biol Rev, 2007. 71: 636-52. DOI: 10.1128/ MMBR.00023-07

54. Vitelli R, Chiariello M, Lattero D, Bruni C B, Bucci C. Molecular cloning and expression analysis of the human Rab7 GTP-ase complementary deoxyribonucleic acid. Biochem Biophys Res Commun, 1996. 229(3): 887-90. DOI: 10.1006/bbrc.1996.1897

55. Papini E, Satin B, Bucci C, de Bernard M, Telford J L, Manetti R, et al., The small GTP binding protein rab7 is essential for cellular vacuolation induced by Helicobacter pylori cytotoxin. EMBOJ 1997; 16: 15-24. DOI: 10.1093/emboj/16.1.15

56. Lin H J, Satin B, Bucci C, de Bernard M, Telford J L,
Manetti R, et al., Helicobacter pylori cagA, iceA and vacA genotypes in patients with gastric cancer in Taiwan. World J Gastroenterol 2004; 10: 2493-2497.

57. Drecktrah D, Knodler L A, Howe D, Steele-Mortimer O. Salmonella trafficking is defined by continuous dynamic interactions with the endolysosomal system. Traffic 2007. 8: 212-225. DOI: 10.1111/j.16000854.2006.00529.x

58. Starr T, Ng TW, Wehrly T D, Knodler L A, Celli J, et al. Brucella intracellular replication requires trafficking through the late endosomal/lysosomal compartment. Traffic 2008. 9: 678-694. DOI: 10.1111/j.16000854.2008.00718.x

59. Saito-Nakano Y, Mitra B N, Nakada-Tsukui K, Sato D, Nozaki T. et al., Two Rab7 isotypes, EhRab7A and EhRab7B, play distinct roles in biogenesis of lysosomes and phagosomes in the enteric protozoan parasite Entamoeba histolytica. Cell Microbiol 2007; 9: 17961808. DOI: 10.1111/j.1462-5822.2007.00915.x

60. Buczynski G, Bush J, Zhang L, Rodriguez-Paris J, Cardelli J. Evidence for a recycling role for Rab7 in regulating a late step in endocytosis and in retention of lysosomal enzymes in Dictyostelium discoideum. Mol Biol Cell 1997; 8: 1343-1360.

61. Rupper A, Grove B, Cardelli J. Rab7 regulates phagosome maturation in Dictyostelium. J Cell Sci 2001; 114(Pt 13): 2449-2460.

62. Gotthardt D, Warnatz H J, Henschel O, Bruckert F, Schleicher M, Soldati T, et al. High-resolution dissection of phagosome maturation reveals distinct membrane trafficking phases. Mol Biol Cell 2002; 13: 3508-3520. DOI: $10.1091 / \mathrm{mbc}$.E02-04-0206

63. Schimmoller F, Riezman H. Involvement of Ypt7p, a small GTPase, in traffic from late endosome to the vacuole in yeast. $J$ Cell Sci 1993; 106 ( Pt 3): 823-830.

64. Gachet Y, Hyams J S. Endocytosis in fission yeast is spatially associated with the actin cytoskeleton during polarised cell growth and cytokinesis. J Cell Sci 2005; 118(Pt 18): 4231-42. DOI: 10.1242/jcs.02530

65. Cogli L, Piro F, Bucci C. Rab7 and the CMT2B disease. Biochem Soc Trans 2009; 37(Pt 5): 1027-31. DOI: 10.1042/BST0371027

66. CogliL, Progida C, Lecci R, Bramato R, Kruttgen A, Bucci C. et al., CMT2B-associated Rab7 mutants inhibit neurite outgrowth. Acta Neuropathol, 2010; 120: 491501. DOI: 10.1007/s00401-010-0696-8 
67. Spinosa M R, Progida C, De Luca A, Colucci A M, Alifano P, Bucci C. Functional characterization of Rab7 mutant proteins associated with Charcot-Marie-Tooth type 2B disease. $J$ Neurosci, 2008. 28: 1640-8. DOI: 10.1523/JNEUROSCI.3677-07.2008

68. BasuRay S, Mukherjee S, Romero E, Wilson M C, Wandinger-Ness A, et al. Rab7 mutants associated with Charcot-Marie-Tooth disease exhibit enhanced NGFstimulated signaling. PLoS One 2010; 5: e15351. DOI: 10.1371/journal.pone.001535

69. BasuRay S, Mukherjee S, Romero E, Seaman M N,Wandinger-Ness A. Rab7 mutants associated with Charcot-Marie-Tooth disease cause delayed growth factor receptor transport and altered endosomal and nuclear signaling. J Biol Chem 2013; 288: 1135-1149. DOI: $10.1074 /$ jbc.M112.417766

70. McCray B A, Skordalakes E, Taylor J P. Disease mutations in Rab7 result in unregulated nucleotide exchange and inappropriate activation. Hum Mol Genet 2010. 19: 1033-1047. DOI: $10.1093 / \mathrm{hmg} / \mathrm{ddp} 567$

71. Wang X, Han C, Liu W, Wang P, Zhang X, et al., A Novel RAB7 Mutation in a Chinese Family with Charcot-Marie-Tooth type 2B disease. Gene 2013; DOI: 10.1016/j.gene.2013.10.023

72. Zhang K, Fishel Ben Kenan R, Osakada Y,Xu W, Sinit R S, Chen L et al., Defective axonal transport of Rab7 GTPase results in dysregulated trophic signaling. J Neurosci, 2013. 33: 7451-7462. DOI: 10.1523/ JNEUROSCI.4322-12.2013

73. Houlden H, King R H, Muddle J R, Warner T T, Reilly M M, Orrell R W et al., A novel RAB7 mutation associated with ulcero-mutilating neuropathy. Ann Neurol 2004; 56: 586-590. DOI: 10.1002/ana.20281

74. Meggouh F, Bienfait H M, Weterman M A, de Visser M, Baas F. Charcot-Marie-Tooth disease due to a de novo mutation of the RAB7 gene. Neurology 2006. 67: 14761478. DOI: 10.1212/01.wnl.0000240068.21499.f5

75. Verhoeven K, De Jonghe P, Coen K, Verpoorten N, Auer-Grumbach M, Kwon J M, et al., Mutations in the small GTP-ase late endosomal protein RAB7 cause Charcot-Marie-Tooth type 2B neuropathy. Am J Hum Genet 2003. 72: 722-727. DOI: 10.1086/367847

76. Rojas R, van Vlijmen T, Mardones G A, Prabhu Y, Rojas A L, Mohammed S, et al., Regulation of retromer recruitment to endosomes by sequential action of Rab5 and Rab7. J Cell Biol 2008. 183: 513-526. DOI:

\subsection{6/367847}

77. Seaman MN, Harbour M E, Tattersall D, Read E, Bright $\mathrm{N}$. Membrane recruitment of the cargo-selective retromer subcomplex is catalysed by the small GTPase Rab7 and inhibited by the Rab-GAP TBC1D5. J Cell Sci 2009; 122(Pt 14): 2371-2382. DOI: 10.1242/jcs.048686

78. McGough IJ, Cullen PJ. Recent advances in retromer biology. Traffic 2011; 12: 96371. DOI: 10.1111/j.16000854.2011.01201.x

79. Reitz C. The role of the retromer complex in agingrelated neurodegeneration: a molecular and genomic review. Mol Genet Genomics, 2014. DOI: 10.1007/ s00438-014-0939-9

80. Vardarajan BN, Bruesegem S Y, Harbour M E, Inzelberg R, Friedland R, St George-Hyslop P, et al., Identification of Alzheimer disease-associated variants in genes that regulate retromer function. Neurobiol Aging 2012; 33: 2231 e15-2231 e30. DOI: 10.1016/j. neurobiolaging.2012.04.020

81. Somsel Rodman J, Wandinger-Ness A. Rab GTPases coordinate endocytosis. J Cell Sci 2000; 113 Pt 2: 183192.

82. Alexandrov K, Horiuchi H, Steele-Mortimer O, Seabra M C, Zerial M. Rab escort protein-1 is a multifunctional protein that accompanies newly prenylated rab proteins to their target membranes. EMBOJ 1994. 13: 5262-5273.

83. Stenmark H, Olkkonen V M. Inhibition of rab5 GTPase activity stimulates membrane fusion in endocytosis. EMBO J 1994. 13(6): 1287-96.

84. Stenmark H, Parton R G, Steele-Mortimer O, Lutcke A, Gruenberg J, Zerial M. Distinct structural elements of rab5 define its functional specificity. EMBO J 1994. 13: 575-583.

85. Grosshans B L, Ortiz D, Novick P. Rabs and their effectors: achieving specificity in membrane traffic. Proc Natl Acad Sci USA 2006; 103: 11821-11827. DOI: 10.1073/pnas.0601617103

86. Markgraf D F, Peplowska K, Ungermann C. Rab cascades and tethering factors in the endomembrane system. FEBS Lett 2007; 581: 2125-2130. DOI: 10.1016/j.febslet.2007.01.090

87. Zhang XM, Walsh B, Mitchell CA, Rowe T. TBC domain family, member 15 is a novel mammalian Rab GTPaseactivating protein with substrate preference for Rab7. Biochem Biophys Res Commun, 2005. 335: 154-161. DOI: 10.1042/BSR20090032 
88. Beraud-Dufour, Balch S W. A journey through the exocytic pathway. J Cell Sci, 2002. 115(Pt 9): 17791780.

89. Rink J, Ghigo E, Kalaidzidis Y, Zerial M. Rab conversion as a mechanism of progression from early to late endosomes. Cell 2005; 122: 735-749. DOI: 10.1016/j. cell.2005.06.043

90. Villen J, Beausoleil S A, Gerber S A, Gygi S P. Largescale phosphorylation analysis of mouse liver. Proc Natl Acad Sci USA 2007; 104: 1488-1493. DOI: 10.1073/ pnas.0609836104

91. Wolf-Yadlin A, Kumar N, Zhang Y, Hautaniemi S, Zaman M, Kim H D, et al., Effects of HER2 overexpression on cell signaling networks governing proliferation and migration. Mol Syst Biol, 2006. 2: 54. DOI: 10.1038/ msb4100094

92. Rikova K, Guo A, Zeng Q, Possemato A, Yu J, Haack $\mathrm{H}$, et al., Global survey of phosphotyrosine signaling identifies oncogenic kinases in lung cancer. Cell 2007. 131(6): 1190-203. DOI: 10.1016/j.cell.2007.11.025

93. Guo F, Letrent S P, Munster P N, Britten C D, Gelmon K, Tolcher A W, et al., Pharmacokinetics of a HER2 tyrosine kinase inhibitor CP-724,714 in patients with advanced malignant HER2 positive solid tumors: correlations with clinical characteristics and safety. Cancer Chemother Pharmacol 2008; 62: 97-109. DOI: 10.1007/s00280007-0579-4

94. Agola JO, Hong L, Surviladze Z, Ursu O, Waller A, Strouse J J, Simpson D S, et al., A competitive nucleotide binding inhibitor: in vitro characterization of Rab7 GTPase inhibition. ACS Chem Biol 2012; 7: 1095-1108. DOI: $10.1021 / \mathrm{cb} 3001099$

95. Hong L, Simons P, Waller A, Strouse J, Surviladze Z, Ursu O, Bologa C, et al., A small molecule pan-inhibitor of Ras-superfamily GTPases with high efficacy towards Rab7. In: Probe Reports from the NIH Molecular Libraries Program 2010: Bethesda, MD.

96. Wang T, Ming Z, Xiaochun W, Hong W. Rab7: role of its protein interaction cascades in endo-lysosomal traffic. Cell Signal 2011; 23: 516-521. DOI: 10.1016/j. cellsig.2010.09.012

97. Cantalupo G, Alifano P, Roberti V, Bruni C B, Bucci C. Rab-interacting lysosomal protein (RILP): the Rab7 effector required for transport to lysosomes. EMBO J 2001; 20: 683-693. DOI: 10.1093/emboj/20.4.683

98. Progida C, Malerod L, Stuffers S, Brech A, Bucci C,
Stenmark H. RILP is required for the proper morphology and function of late endosomes. J Cell Sci 2007; 120(Pt 21): 3729-3737. DOI: $10.1242 /$ jcs. 017301

99. Harrison RE, Brumell J H, Khandani A, Bucci C, Scott C C, Jiang X, et al., Salmonella impairs RILP recruitment to Rab7 during maturation of invasion vacuoles. Mol Biol Cell, 2004. 15: 3154. DOI: 10.1091/mbc.E04-02-0092

100. Sun J, Deghmane A E, Soualhine H, Hong T, Bucci C, Solodkin A, et al., Mycobacterium bovis BCG disrupts the interaction of Rab7 with RILP contributing to inhibition of phagosome maturation. J Leukoc Biol 2007; 82: 1437-1445. DOI: 10.1189/jlb.10.1189

101. Johansson M, Rocha N, Zwart W, Jordens I, Janssen L, Kuijl C, et al., Activation of endosomal dynein motors by stepwise assembly of Rab7-RILPp150Glued, ORP1L, and the receptor betalll spectrin. J Cell Biol 2007. 176: 459-471. DOI: $10.1083 / \mathrm{jcb} .200606077$

102. Rocha N, Kuijl C, van der Kant R, Janssen L, Houben $\mathrm{D}$, Janssen $\mathrm{H}$, et al., Cholesterol sensor ORP1L contacts the ER protein VAP to control Rab7-RILPp150 Glued and late endosome positioning. J Cell Biol, 2009. 185(7): 1209-25. DOI: $10.1083 /$ jcb.200811005

103. van der Kant R, Fish A, Janssen L, Janssen H, Krom S, Ho $\mathrm{N}$, et al., Late endosomal transport and tethering are coupled processes controlled by RILP and the cholesterol sensor ORP1L. J Cell Sci, 2013. 126(Pt 15): 3462-74. DOI: $10.1242 /$ jcs. 129270

104. Caviston J P, Zajac A L, Tokito M, Holzbaur E L. Huntingtin coordinates the dynein-mediated dynamic positioning of endosomes and lysosomes. Mol Biol Cell 2011; 22: 478-492. DOI: 10.1091/mbc.E10-03-0233

105. Loubery S, Wilhelm C, Hurbain I, Neveu S, Louvard D, Coudrier E. Different microtubule motors move early and late endocytic compartments. Traffic, 2008. 9(4): 492-509. DOI: 10.1111/j.1600-0854.2008.00704.x

106. Jackson L K, Nawabi P, Hentea C, Roark E A, Haldar $\mathrm{K}$. The Salmonella virulence protein SifA is a G protein antagonist. Proc Natl Acad Sci USA 2008; 105(37): 14141-6. DOI: 10.1073/pnas.0801872105

107. Chen H, Yang J, Low P S, Cheng J X. Cholesterol level regulates endosome motility via Rab proteins. Biophys J 2008. 94: 1508-1520. DOI: 10.1529/ biophysj.106.099366

108. Zhang M, Chen L, Wang S, Wang T. Rab7: roles in membrane trafficking and disease. Biosci Rep 2009; 29: 193-209. DOI: 10.1042/BSR20090032 
109. Ho CY, Alghamdi T A, Botelho R J. Phosphatidylinositol3,5-bisphosphate: no longer the poor PIP2. Traffic 2012; 13: 1-8. DOI: 10.1111/j.1600-0854.2011.01246.x

110. Dong J, Chen W, Welford A, Wandinger-Ness A. The proteasome alpha-subunit XAPC7 interacts specifically with Rab7 and late endosomes. $J$ Biol Chem, 2004.;279: 21334-21342. DOI: 10.1074/jbc. M401022200

111. Mukherjee S, Dong J, Heincelman C, Lenhart M, Welford A, Wandinger-Ness A. Functional analyses and interaction of the XAPC7 proteasome subunit with Rab7. Methods Enzymol 2005; 403: 650-63. DOI: 10.1016/ S0076-6879(05)03056-9

112. Sato K, W Wickner. Functional reconstitution of ypt7p GTPase and a purified vacuole SNARE complex. Science 1998; 281: 700-702.

113. Kuriyama H, Asakawa S, Minoshima S, Maruyama H, Ishii $\mathrm{N}$, Ito $\mathrm{K}$, et al. Characterization and chromosomal mapping of a novel human gene, ANKHZN. Gene 2000. 253: 151-160.

114. Dautry-Varsat A. Receptor-mediated endocytosis: the intracellular journey of transferrin and its receptor. Biochimie 1986. 68: 375-381.

115. Nordmann M, Cabrera M, Perz A, Brocker C, Ostrowicz C, Engelbrecht-Vandre S, et al. The Mon1-Ccz1 complex is the GEF of the late endosomal Rab7 homolog Ypt7. Curr Biol 2010; 20: 1654-9. DOI: 10.1016/j. cub.2010.08.002

116. Pankiv S, Alemu E A, Brech A, Bruun J A, Lamark T, Overvatn A, et al. FYCO1 is a Rab7 effector that binds to LC3 and PI3P to mediate microtubule plus end-directed vesicle transport. J Cell Biol 2010; 188: 253-269. DOI: 10.1083/jcb.200907015

117. Seals D F, Eitzen G, Margolis N, Wickner W T, Price A. A Ypt/Rab effector complex containing the Sec1 homolog Vps33p is required for homotypic vacuole fusion. Proc Natl Acad Sci USA 2000; 97: 9402-9407.

118. Wurmser A E,Sato T K, Emr S D. New component of the vacuolar class $\mathrm{C}-\mathrm{Vps}$ complex couples nucleotide exchange on the Ypt7 GTPase to SNARE-dependent docking and fusion. J Cell Biol 2000. 151: 551-562.

119. Peralta E R,Martin B C, Edinger A L. Differential effects of TBC1D15 and mammalian Vps39 on Rab7 activation state, lysosomal morphology, and growth factor dependence. J Biol Chem 2010; 285: 1681416821. DOI: $10.1074 /$ jbc.M110.111633
120. Bananis E, Nath S, Gordon K, Satir P, Stockert R J, Murray J W, et al., Microtubule-dependent movement of late endocytic vesicles in vitro: requirements for dynein and kinesin. Mol Biol Cell 2004; 15: 3688-97. DOI: 10.1091/mbc.E04-04-0278

121. Cheli V T, Dell'Angelica E C. Early origin of genes encoding subunits of biogenesis of lysosome-related organelles complex-1, -2 and -3. Traffic 2010; 11: 579586. DOI: 10.1111/j.1600-0854.2010.01044.x

122. Kinchen J M, Ravichandran K S. Identification of two evolutionarily conserved genes regulating processing of engulfed apoptotic cells. Nature 2010; 464: 778-782. DOI: 10.1038/nature08853

123. Poteryaev D, Datta S, Ackema K, Zerial M, Spang A. Identification of the switch in early-to-late endosome transition. Cell 2010; 141: 497-508. DOI: 10.1016/j. cell.2010.03.011

124. Stein M P, Cao C, Tessema M, Feng Y, Romero E, Welford A, et al., Interaction and functional analyses of human VPS34/p150 phosphatidylinositol 3-kinase complex with Rab7. Methods Enzymol 2005; 403: 628649. DOI: 10.1016/S0076-6879(05)03055-7

125. Van Wesenbeeck L, Odgren P R, Coxon F P, Frattini A, Moens P, Perdu B, et al., Involvement of PLEKHM1 in osteoclastic vesicular transport and osteopetrosis in incisors absent rats and humans. J Clin Invest 2007; 117: 919-930. DOI: 10.1172/JCI30328

126. Sakane A, Hatakeyama S, Sasaki T. Involvement of Rabring7 in EGF receptor degradation as an E3 ligase. Biochem Biophys Res Commun 2007. 357: 1058-1064. DOI: $10.1016 /$ j.bbrc.2007.04.052

127. Nakada-Tsukui K, Saito-Nakano Y, Ali V, Nozaki T. A retromer-like complex is a novel Rab7 effector that is involved in the transport of the virulence factor cysteine protease in the enteric protozoan parasite Entamoeba histolytica. Mol Biol Cell 2005; 16: 5294-5303. DOI: 10.1091/mbc.E05-04-0283

128. Jordens I, Fernandez-Borja M, Marsman M, Dusseljee S, Janssen L, Calafat J, et al., The Rab7 effector protein RILP controls lysosomal transport by inducing the recruitment of dynein-dynactin motors. Curr Biol 2001; 11: 1680-1685.

129. Sun Q, Westphal W, Wong K N, Tan I, Zhong Q. Rubicon controls endosome maturation as a Rab7 effector. Proc Natl Acad Sci USA 2010. 107: 19338-43. DOI: 10.1073/ pnas. 1010554107 
130. Boucrot E, Henry T, Borg J P, Gorvel J P, Meresse S. The intracellular fate of Salmonella depends on the recruitment of kinesin. Science 2005; 308: 1174-1178. DOI: $10.1126 /$ science. 1110225

131. Ohlson M B, Huang Z, Alto N M, Blanc M P, Dixon J $\mathrm{E}$, Chai J,et al., Structure and function of Salmonella SifA indicate that its interactions with SKIP, SseJ, and RhoA family GTPases induce endosomal tubulation. Cell Host Microbe 2008; 4: 434-446. DOI: 10.1016/j. chom.2008.08.012

132. Carroll B, Mohd-Naim N, Maximiano F, Frasa M A, McCormack J, Finelli M, et al., The TBC/RabGAP Armus coordinates Rac1 and Rab7 functions during autophagy. Dev Cell 2013; 25: 15-28. DOI: 10.1016/j. devcel.2013.03.005
133. Frasa MA, Maximiano F C, Smolarczyk K, Francis $\mathrm{R}$ E, Betson M E, Lozano E, et al. Armus is a Rac1 effector that inactivates Rab7 and regulates E-cadherin degradation. Curr Biol 2010; 20: 198-208. DOI: 10.1016/j.cub.2009.12.053

134. Sender V, Moulakakis C, Stamme C. Pulmonary surfactant protein A enhances endolysosomal trafficking in alveolar macrophages through regulation of Rab7. J Immunol 2011; 186: 2397-2411. DOI: 10.4049/ jimmunol.1002446

135. Kim JY, Jang MK, Lee SS, Choi MS, Bok SH, Oh GT, et al. Rab7 gene is up-regulated by cholesterol-rich diet in the liver and artery. Biochem Biophys Res Commun 2002; 293: 375-382. 